\title{
Flowcharts for the management of biliary tract and ampullary carcinomas
}

\author{
Shuichi Miyakawa ${ }^{1}$, Shin Ishihara ${ }^{1}$, Tadahiro Takada ${ }^{2}$, Masaru Miyazaki $^{3}$, Kazuhiro Tsukada $^{4}$, \\ Masato Nagino ${ }^{5}$, Satoshi Kondo ${ }^{6}$, Junji Furuse ${ }^{7}$, Hiroya Saito $^{8}$, Toshio Tsuyuguchi ${ }^{9}$, Fumio Kimura ${ }^{3}$, \\ Hideyuki Yoshitomi ${ }^{3}$, Satoshi Nozawa ${ }^{3}$, Masahiro Yoshida ${ }^{2}$, Keita Wada ${ }^{2}$, Hodaka Amano ${ }^{2}$, \\ and FUMIHIKO MIURA ${ }^{2}$ \\ ${ }^{1}$ Department of Gastroenterological Surgery, Fujita Health University, 1-98 Dengakugakubo, Kutsukake-cho, Toyoake, Aichi 470-1192, Japan \\ ${ }^{2}$ Department of Surgery, Teikyo University School of Medicine, Tokyo, Japan \\ ${ }^{3}$ Department of General Surgery, Chiba University Graduate School of Medicine, Chiba, Japan \\ ${ }^{4}$ Department of Surgery and Science, Graduate School of Medicine and Pharmaceutical Science for Research, University of Toyama, Toyama, \\ Japan \\ ${ }^{5}$ Division of Surgical Oncology, Department of Surgery, Nagoya University Graduate School of Medicine, Nagoya, Japan \\ ${ }^{6}$ Department of Surgical Oncology, Hokkaido University Graduate School of Medicine, Sapporo, Japan \\ ${ }^{7}$ Hepatobiliary and Pancreatic Oncology Division, National Cancer Center Hospital East, Chiba, Japan \\ ${ }^{8}$ Department of Radiology, Asahikawa Kosei General Hospital, Asahikawa, Japan \\ ${ }^{9}$ Department of Medicine and Clinical Oncology, Chiba University Graduate School of Medicine, Chiba, Japan
}

\begin{abstract}
No strategies for the diagnosis and treatment of biliary tract carcinoma have been clearly described. We developed flowcharts for the diagnosis and treatment of biliary tract carcinoma on the basis of the best clinical evidence. Risk factors for bile duct carcinoma are a dilated type of pancreaticobiliary maljunction (PBM) and primary sclerosing cholangitis. A nondilated type of PBM is a risk factor for gallbladder carcinoma. Symptoms that may indicate biliary tract carcinoma are jaundice and pain in the upper right area of the abdomen. The first step of diagnosis is to carry out blood biochemistry tests and ultrasonography (US) of the abdomen. The second step of diagnosis is to find the local extension of the carcinoma by means of computed tomography (CT), magnetic resonance imaging (MRI), magnetic resonance cholangiopancreatography (MRCP), percutaneous transhepatic cholangiography (PTC), and endoscopic retrograde cholangiopancreatography (ERCP). Because resection is the only way to completely cure biliary tract carcinoma, the indications for resection are determined first. In patients with resectable disease, the indications for biliary drainage or portal vein embolization (PVE) are checked. In those with nonresectable disease, biliary stenting, chemotherapy, radiotherapy, and/or best supportive care is selected.
\end{abstract}

Key words Biliary tract carcinoma - Bile duct carcinoma . Gallbladder carcinoma - Ampullary carcinoma - Guidelines

Offprint requests to: S. Miyakawa

Received: October 1, 2007 / Accepted: October 22, 2007

\section{Introduction}

There have been no reports of a comprehensive clinical system to cover all entities of bile duct carcinoma, gallbladder carcinoma, and ampullary carcinoma. In addition, there is no clear consensus as to the best methods of diagnosis and treatment of biliary tract carcinoma. We therefore developed flowcharts for the diagnosis and treatment of biliary tract carcinoma, on the basis of the best clinical evidence provided until 2007. Six levels of evidence were used (see definitions of levels in Table $1^{1}$ ), and the levels are noted here in parentheses after the citations of relevant references. The flowchart for diagnosis consists of: (1) risk factors, (2) clinical presentation, (3) the first step of diagnosis, and (4) the second step of diagnosis. The flowchart for treatment consists of: (1) resectable cases and (2) nonresectable cases.

\section{Flowchart for the diagnosis of biliary tract carcinoma}

The flowchart for the diagnosis of biliary tract carcinoma is shown in Fig. 1.

\section{Risk factors}

Risk factors for bile duct carcinoma are a dilated type of pancreaticobiliary maljunction (PBM) and primary sclerosing cholangitis. Biliary tract carcinoma occurred in $10.6 \%$ of patients with a dilated type of PBM, and bile duct carcinoma occurred in $33.6 \%$ of such patients $^{2}$ (level IV). Bile duct carcinoma occurred in 5\%$10 \%$ of patients with primary sclerosing cholangitis ${ }^{3-6}$ (level V). 
A nondilated type of PBM is a risk factor for gallbladder carcinoma. Biliary tract carcinoma occurred in $37.9 \%$ of patients with a nondilated type of PBM, while gallbladder carcinoma occurred in $93.2 \%$ of such patients $^{2}$ (level IV).

No risk factor is known for ampullary carcinoma.

\section{Clinical presentation}

Symptoms that may indicate biliary tract carcinoma are jaundice and pain in the upper right area of the abdomen.
For $90 \%$ of patients with bile duct carcinoma, the presenting symptom was jaundice, (level IV). In patients without jaundice, the presenting symptom was pain in the abdomen, fever, anorexia, or lassitude ${ }^{2,7-9}$ (level IV).

The symptom most often seen in gallbladder carcinoma is pain in the upper right area of the abdomen ${ }^{10,11}$ (level IV). Other signs and symptoms are nausea, vomiting, loss of weight, jaundice, anorexia, a feeling of abdominal distension, pruritus, and black feces ${ }^{10}$ (level IV).

Symptoms of ampullary carcinoma in many patients are jaundice, fever, and abdominal pain ${ }^{12,13}$ (level IV).

Table 1. Levels of evidence ${ }^{1}$

$\begin{array}{ll}\text { Level I } & \text { Systematic review/meta-analysis } \\ \text { Level II } & \text { One or more randomized clinical trials } \\ \text { Level III } & \text { Nonrandomized controlled trials } \\ \text { Level IV } & \text { Analytic epidemiology (cohort studies and case-control studies) } \\ \text { Level V } & \text { Descriptive study (case reports and case-series studies) } \\ \text { Level VI } & \begin{array}{l}\text { Opinions of expert panels and individual experts not based on } \\ \text { patient's data }\end{array}\end{array}$

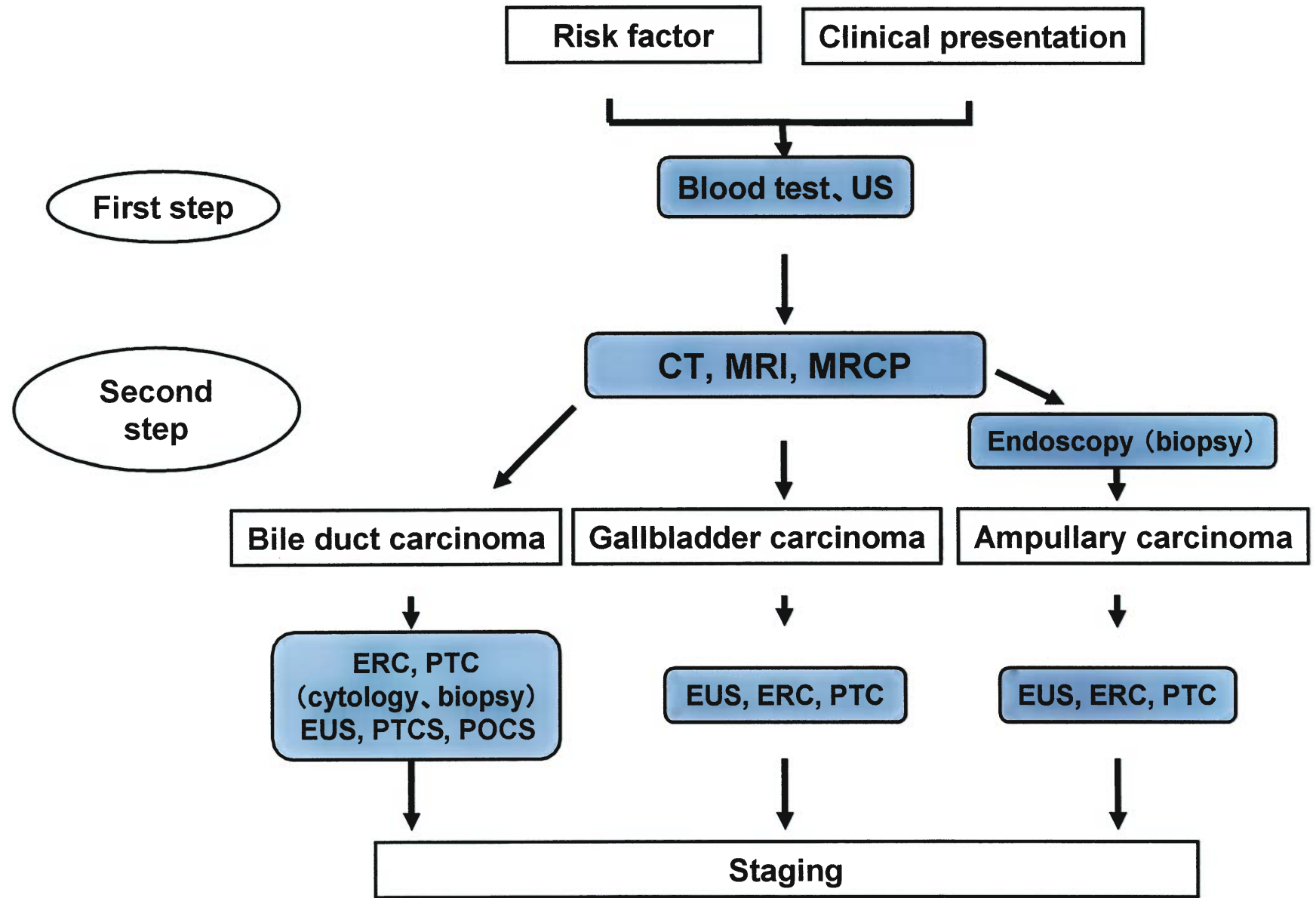

Fig. 1. Flowchart for the diagnosis of biliary tract and ampullary carcinomas. US, Ultrasonography; $C T$, computed tomography; $M R I$, magnetic resonance imaging; $M R C P$, magnetic resonance cholangiopancreatography; $E R C$, endoscopic retro- grade cholangiography; $P T C$, percutaneous transhepatic cholangiography; EUS, endoscopic ultrasonography; PTCS, percutaneous transhepatic cholangioscopy; $P O C S$, peroral cholangioscopy 


\section{First step of diagnosis}

The first step of diagnosis is to carry out blood biochemistry tests and ultrasonography (US) of the abdomen. In blood biochemistry tests in patients with bile duct obstruction, rises in hepatobiliary enzymes are observed $^{14,15}$ (level III). Carbohydrate antigen (CA) 199 is elevated in $50 \%-79 \%$ of patients with biliary tract carcinoma $^{16-19}$ (levels II and III), and carcinoembryonic antigen (CEA) is elevated in $40 \%-70 \%$ of such patients $^{19-21}$ (level III).

If there is a suspicion of biliary tract carcinoma, US is the first diagnostic imaging to be applied. If dilation of the bile duct is found, it is possible to identify the obstructed region $^{14,15}$ (level III). For gallbladder carcinoma, the tumor is identified by US in more than $50 \%$ of patients ${ }^{14}$ (level III).

\section{Second step of diagnosis}

\section{Bile duct carcinoma}

Computed tomography (CT) and magnetic resonance imaging (MRI; including magnetic resonance cholangiopancreatography [MRCP]) are useful to check on the location of bile duct carcinoma or to find the local extension of such carcinoma. Contrast-enhanced CT is useful for finding the main local extension of cancer. In addition, examining whether there is invasion of the cancer into blood vessels by means of contrast-enhanced CT is important for deciding how to treat the cancer ${ }^{22-24}$ (level II-IV). In bile duct carcinoma without thickening of biliary walls, it is difficult to identify local extension or depth only by means of $\mathrm{CT}^{22,23}$ (levels II and IV).

MRCP is useful for identifying the obstructed region in the bile duct, for finding the local extension of the carcinoma, and for checking on $\mathrm{PBM}^{25}$ (level IV). MRCP has a sensitivity of $70 \%-96 \%$ in determining whether a bile duct stricture is of benign/malignant nature, and is able to identify obstructed regions with a sensitivity of $94 \%-99 \%{ }^{26-28}$ (levels III and IV).

Endoscopic retrograde cholangiopancreatography (ERCP) and percutaneous transhepatic cholangiography (PTC) are useful for examining the horizontal invasion of nodular bile duct carcinoma, and for indicating nodular and invasive bile duct carcinoma ${ }^{29,30}$ (level IV).

Examination of cells or tissues is carried out as required. The positive rate of bile cytology determined by means of endoscopic retrograde cholangiography (ERC) is about $30 \%{ }^{25}$ (level II). A combination of brush cytology and biopsy of the bile duct increases the positive rate to $40 \%-70 \%{ }^{25}$ (level II).

Percutaneous transhepatic cholangioscopy $(\text { PTCS })^{31-33}$ and peroral cholangioscopy (POCS) $)^{34,35}$ enable close examination of the lumen of the bile duct.
These modalities are useful in both differentiating benign and malignant biliary strictures and in diagnosing the superficial mucosal spread of bile duct carcinoma along the bile duct wall.

\section{Gallbladder carcinoma}

In the diagnosis of gallbladder carcinoma, differential diagnosis and determination of the local extension of tumor are important. For these purposes, imaging modalities such as endoscopic ultrasonography (EUS), CT, MRI, and MRCP are useful. EUS has good sensitivity, of $92 \%-97 \%$, in differentiating benign gallbladder diseases from gallbladder carcinoma ${ }^{36-38}$ (level IV). CT has a capability of diagnosis of tumorous lesions in the gallbladder with a sensitivity of $88 \%$, a specificity of $87 \%$, and a correct diagnosis rate of $87 \%{ }^{39}$ (level IV). In a report that evaluated the diagnosis of the resectability of gallbladder carcinoma, accuracy of the diagnosis of resectability with CT was $93.3 \%{ }^{40}$ (level IV). According to some reports, in the diagnosis of direct invasion of tumor into the liver, MRI combined with MRCP had a sensitivity of $67 \%-100 \%$ and a specificity of $89 \%$; in the diagnosis of invasion of tumor into the bile duct, it had a sensitivity of $62 \%-100 \%$ and a specificity of $89 \%$; and in the diagnosis of cancer metastasis to lymph nodes, it had a sensitivity of $56 \%-92 \%$ and a specificity of $89 \%^{41,42}$ (level IV).

\section{Ampullary carcinoma}

For the examination of ampullary carcinoma, endoscopic biopsy is used. For the examination of distant metastasis of cancer, e.g., to the liver, US, CT, and MRI are used. For the examination of invasion to the pancreas or the duodenum, EUS or intraductal ultrasonography (IDUS) is usefull ${ }^{43,44}$ (level II).

\section{Flowchart for the treatment of biliary tract carcinoma}

The flowchart for the treatment of biliary tract carcinoma is shown in Fig. 2.

\section{Indications for resection}

Resection is the only radical treatment for biliary tract carcinoma. Its possibility should, therefore, be considered first. If such cancer involves metastasis to the liver, the lung or the peritoneum, it is not resectable $e^{45-47}$ (level IV). On the other hand, there is a report which advocates surgery for patients with paraaoric lymph node metastasis, because the outcome is expected to be improved by surgery ${ }^{48,49}$ (level IV). However, there is no consensus on standards for local extension factors or on the level of metastasis of lymph nodes that would determine whether the cancer is nonresectable. 


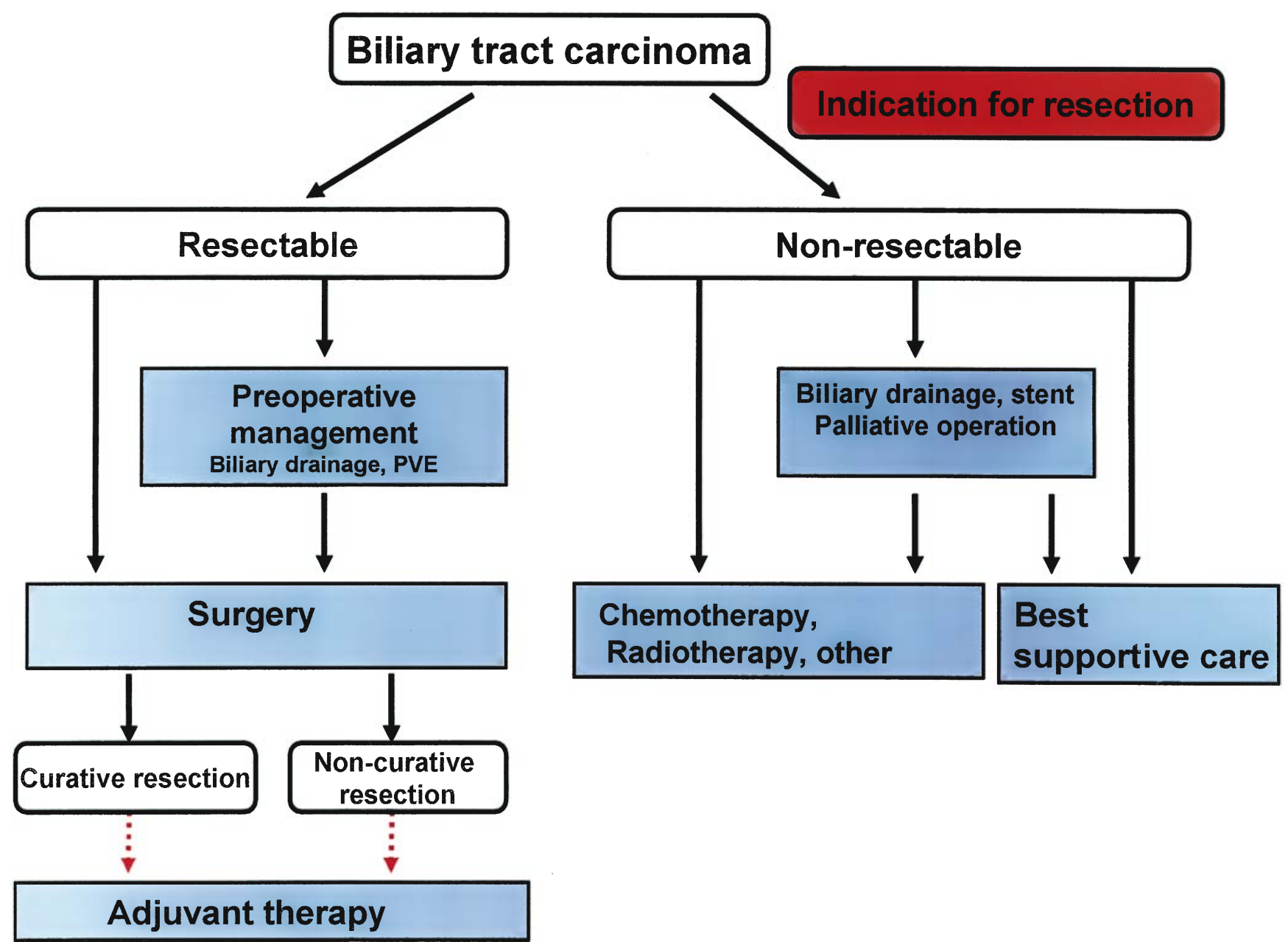

Fig. 2. Flowchart for the treatment of biliary tract and ampullary carcinomas. $P V E$, Portal vein embolization

\section{Resectable cancers}

Preoperative management

Biliary drainage. Many reports suggest that, except for patients with cholangitis or hepatic disorders, surgical operations that are as invasive as pancreatoduodenectomy do not need preoperative biliary drainage $e^{50-54}$ (levels IV and VI). The mortality from complications in major hepatectomy is about $10 \%$, and the main cause of death is hepatic failure ${ }^{55}$ (level IV). In patients with severe jaundice, therefore, biliary drainage is carried out before surgical operation. For biliary drainage, it is, in principle, sufficient to drain only the future remnant liver. However, there are no standards for indications for such drainage.

Portal vein embolization ( $P V E$ ). In patients who require right hemihepatectomy and more extended hepatectomy, or $50 \%-60 \%$ hepatectomy, particularly patients with obstructive jaundice, PVE may be performed. It may reduce postoperative complications or deaths related to the operations ${ }^{56-62}$ (levels III and IV).

\section{Surgery}

The results of surgical treatment of biliary tract carcinoma have been improved with various new procedures.

Bile duct carcinoma. For hilar cholangiocarcinoma and upper bile duct carcinoma, extrahepatic bile duct resection with hepatectomy is a standard surgical procedure; and for middle or lower bile duct carcinoma, pancreatoduodenectomy is a standard procedure. For many patients with hilar cholangiocarcinoma, combined resection of the caudate lobe is recommended ${ }^{63-65}$ (level IV); however, there is a report which describes that caudate lobe resection did not influence the outcome of patients with hilar cholangiocarcinoma ${ }^{66}$. In patients with upper or middle bile duct carcinoma, resection of the extrahe- 
patic bile duct is indicated in those patients with papillary lesions localized in such regions, without clear metastasis to lymph nodes ${ }^{67-69}$ (level IV). In addition, it is preferable to confirm a negative surgical margin in intraoperative rapid pathological examination. Combined resection of the portal vein in patients with tumor invasion into the portal vein resulted in a more satisfactory outcome than that seen in nonresectable patients $^{70-74}$ (level IV). So this combined resection may be performed.

Gallbladdercarcinoma. Gallbladder carcinomainvolves various modes of extension to adjacent organs, such as invasion into the liver, hepatoduodenal ligament, duodenum, or transverse colon. So it is important to select the type of surgical operation according to the mode of extension on a case-by-case basis, aiming at no residual tumor $^{75,76}$ (level IV).

Ampullary carcinoma. For this carcinoma, the standard operation is pancreatoduodenectomy. The indication for carcinoma in adenoma is minimally invasive surgery $^{77-79}$ (level IV).

\section{Adjuvant therapy}

For chemotherapy, there are no recommendable regimens, so such therapy is used on a trial basis. For radiotherapy, some reports have stated that it was useful; however, there is no highly reliable evidence for standard therapy ${ }^{80-83}$ (level IV). Accordingly, radiotherapy may be used in patients who have a positive surgical margin postoperatively ${ }^{84}$ (level IV). However, one should be cautious in using radiotherapy in patients with curative resection.

\section{Nonresectable cancers}

Biliary drainage and stenting

For patients with lower bile duct obstruction, biliary stenting is carried out. The stenting is preferably by an endoscopic route ${ }^{85,86}$ (level II). For the type of stent, a metal stent is recommended for patients with lower bile duct obstruction $^{87-92}$ (level II).

\section{Chemotherapy, radiotherapy, and photodynamic therapy}

Chemotherapy. For patients in a good general state, chemotherapy is applied ${ }^{93-96}$ (levels II and IV). No standard chemotherapy has yet been established. A combination therapy regimen with gemcitabine hydrochloride is now in a phase II study.

Radiotherapy. It is reported that radiotherapy has a better effect in improving survival time than palliative therapy ${ }^{97,98}$ (level IV). In addition, another advantage of radiotherapy is that the patency of the stent may be maintained and pain may be reduced by local control.

Photodynamic therapy. It is recognized that photodynamic therapy combined with biliary stenting has a significantly better effect in improving survival time than biliary stenting only ${ }^{99,100}$ (level II).

\section{Best supportive care}

For patients in whom chemotherapy and radiotherapy are not indicated due to a poor general state or persistent jaundice, best supportive care, such as pain control, should be applied for the purpose of maintaining quality of life.

Acknowledgment. We would like to express our deep gratitude to the members of the the Japanese Association of Biliary Surgery, the Japanese Society of HepatoBiliary-Pancreatic Surgery, and the Japan Society of Clinical Oncology, who provided us with great support and guidance in the preparation of the Guidelines. This process was conducted as part of the Integrated Research Project for Assessing Medical Technology 2005 and 2006 sponsored by the Japanese Ministry of Health, Labour, and Welfare.

We truly appreciate the following active working members who developed the draft of the evidencebased clinical practice Guidelines for the treatment of biliary tract cancer (Japanese version, 2007): Masahiro Kai (Miyazaki), Yasutoshi Kimura (Sapporo), Shigeaki Sawada (Toyama), Hiroaki Shimizu (Chiba), Hisatoshi Nakagawara (Kanazawa), Kohei Nakachi (Kashiwa), and Hiroyuki Yoshitome (Chiba). We also appreciate very much the following members who reviewed and approved the final Japanese version of the guidelines: Hiromitsu Saisyo (Ichikawa), Munemasa Ryu (Chiba), Satoru Shikata (Kyoto), and Yuji Nimura (Nagoya).

\section{References}

1. Takada T, Miyazaki M, Miyakawa S, Tsukada K, Nagino M, Kondo S, et al. Purpose, use, and preparation of clinical practice guidelines for the management of biliary tract and ampullary carcinomas. J Hepatobiliary Pancreat Surg 2008;15:2-6.

2. Tashiro S, Imaizumi T, Ohkawa H, Okada A, Katoh T, Kawarada $\mathrm{Y}$, et al. Pancreaticobiliary maljunction: retrospective and nationwide survey in Japan. J Hepatobiliary Pancreat Surg 2003;10: $345-51$.

3. Rosen CB, Nagorney DM, Wiesner RH, Coffey RJ Jr, Larusso NF. Cholangiocarcinoma complicating primary sclerosing cholangitis. Ann Surg 1991; 213:21-5.

4. Rosen CB, Nagorney DM. Cholangiocarcinoma complicating primary sclerosing cholangitis. Semin Liver Dis 1991;11:2630.

5. Callea F, Sergi C, Fabbretti G, Brisigotti M, Cozzutto C, Medicina D. Precancerous lesions of the biliary tree. J Surg Oncol Suppl 1993;3:131-3. 
6. Franco J, Saeian K. Biliary tract inflammatory disorders, primary sclerosing cholangitis and primary biliary cirrhosis. Curr Gastroenterol Rep 1999;1:95-101.

7. Thuluvath PJ, Rai R, Venbrux AC, Yeo CJ. Cholangiocarcinoma: a review. Gastroenterologist 1997;5:306-15.

8. Yeo CJ, Pitt HA, Cameron JL. Cholangiocarcinoma. Surg Clin N Am 1990;70:1429-47.

9. Sugiyama M, Atomi Y, Kuroda A, Muto T. Bile duct carcinoma without jaundice: clues to early diagnosis. Hepatogastroenterology 1997:44:1477-83

10. Malik IA. Clinicopathological features and management of gallbladder cancer in Pakistan: a prospective study of 233 cases. J Gastroenterol Hepatol 2003;18:950-3.

11. Al-Quadah MS, Daradkeh S, Sroujieh AS, Farah GR, Masaad J. Gallbladder carcinoma in Jordan. Hepatogastroenterology 2005; 61:5-7.

12. Nieveen Van Dijkum EJ, Terwee CB, Oosterveld P, Van Der Meulen JH, Gouma DJ, De Haes JC. Validation of the gastrointestinal quality of life index for patients with potentially operable periampullary carcinoma. Br J Surg 2000;87:110-5.

13. Kamisawa T, Tu Y, Egawa N, Nakajima H, Horiguchi S, Tsuruta $\mathrm{K}$, et al. Clinicopathologic features of ampullary carcinoma without jaundice. J Clin Gastroenterol 2006;40:162-6.

14. de Groen PC, Gores GJ, LaRusso NF, Gunderson LL, Nagorney DM. Biliary tract cancers. New Engl J Med 1999;341:1368-79.

15. Khan SA, Thomas HC, Davidson BR, Taylor-Robinson SD. Cholangiocarcinoma. Lancet 2005; 366:1303-14.

16. Misra S, Chaturvedi A, Misra NC, Sharma ID. Carcinoma of the gallbladder. Lancet Oncol 2003;4:167-76.

17. Piantino P, Fusaro A, Randone A, Cerchier A, Daziano E. Increased levels of CA19-9, CA50 and CA125 in patients with benign disease of biliary tract and the pancreas. J Nucl Med Allied Sci 1990;34:97.

18. Patel AH, Harnois DM, Klee GG, LaRusso NF, Gores GJ. The utility of CA 19-9 in the diagnoses of cholangiocarcinoma in patients without primary sclerosing cholangitis. Am J Gastroenterol 2000;95:204-7.

19. Nichols JC, Gores GJ, LaRusso NF, Wiesner RH, Nagorney DM, Ritts RE Jr. Diagnostic role of serum CA 19-9 for cholangiocarcinoma in patients with primary sclerosing cholangitis. Mayo Clin Proc 1993;68:874-9.

20. Khan SA, Davidson BR, Goldin R, Pereira SP, Rosenbera WM, Taylor-Robinson SD, et al. Guidelines for the diagnosis and treatment of cholangiocarcinoma: consensus document. Gut 2002; 51:1-9.

21. Pasanen PA, Eskelinen M, Partanen K, Pikkarainen P, Pentillä I, Alhava E. Clinical value of serum tumor markers CEA, CA50 and CA242 in the distinction between malignant versus benign diseases causing jaundice and cholestasis; results from a prospective study. Anticancer Res 1992;12:1687-93.

22. Han JK, Choi BI, Kim AY, An SK, Lee JW, Kim TK, et al. Cholangiocarcinoma: pictorial essay of CT and cholangiographic findings. Radiographics 2002;22:173-87.

23. Khan SA, Davidson BR, Goldin R, Pereria SP, Rosenbera WM, Taylor-Robinson SD, et al. Guidelines for the diagnosis and treatment of cholangiocarcinoma: consensus document. Gut 2002; $51: 1-9$.

24. Chen HW, Pan AZ, Zhen ZJ, Su SY, Wang JH, Yu SC, et al. Preoperative evaluation of resectability of Klatskin tumor with 16MDCT angiography and cholangiography. AJR Am J Roentgenol 2006;186:1580-6.

25. Lopera JE, Soto JA, Munera F. Malignant hilar and perihilar biliary obstruction: use of MR cholangiography to define the extent of biliary ductal involvement and plan percutaneous interventions. Radiology 2001;220:90-6.

26. Romagnuolo J, Bardou M, Rahme E, Joseph L, Reinhold C, Barkun AN. Magnetic resonance cholangiopancreatography: a meta-analysis of test performance in suspected biliary disease. Ann Intern Med 2003;139:547-57.
27. Barish MA, Yocel EK, Ferrucci JT. Magnetic resonance cholangiopancreatography. New Engl J Med 1999;341:25864.

28. Park MS, Kim TK, Kim KW, Perk SW, Lee JK, Kim JS, et al. Differentiation of extrahepatic bile duct cholangiocarcinoma from benign stricture: findings at MRCP versus ERCP. Radiology 2004;233:234-40.

29. Sakamoto E, Nimura Y, Hayakawa N, Kamiya J, Kondo S, Nagino $\mathrm{M}$, et al. The pattern of infiltration at the proximal border of hilar bile duct carcinoma: a histologic analysis of 62 resected cases. Ann Surg 1998;227:405-11.

30. Hayashi S, Miyazaki M, Kondo Y, Nakajima Nl. Invasive growth patterns of hepatic hilar ductal carcinoma. A histologic analysis of 18 surgical cases. Cancer 1994;73:2922-9.

31. Takada T, Hanyu F, Kobayashi S, Mikoshiba Y, Hamano K. Percutaneous transhepatic cholangiodrainage and cholangioscopy for the case of severe obstructive jaundice caused by pancreatic tumor. In: Stefanini P, Speranza V, editors. Proceedings of the $18^{\text {th }}$ World Congress of the Int Coll Surg. New York: Excerpta Medica Amsterdam American Elsevier; 1973.

32. Nimura Y, Kamiya J, Hayakawa N, Shionoya S. Cholangioscopic differentiation of biliary strictures and polyps. Endoscopy 1989;21 (Suppl 1):351-6.

33. Nimura Y. Staging of biliary carcinoma: cholangiography and cholangioscopy. Endoscopy 1993;25:76-80.

34. Itoi T, Sofuni A, Itokawa F, Tsuchiya T, Kurihara T, Ishii K, et al. Peroral cholangioscopic diagnosis of biliary-tract diseases by using narrow-band imaging (with videos). Gastrointest Endosc 2007;66:730-6.

35. Fukuda Y, Tsuyuguchi T, Sakai Y, Tsuchiya S, Saisyo H. Diagnostic utility of peroral cholangioscopy for various bile-duct lesions. Gastrointest Endosc 2005;62:374-82.

36. Sugiyama M, Atomi Y, Yamato T. Endoscopic ultrasonography for differential diagnosis of polypoid gall bladder lesions: analysis in surgical and follow up series. Gut 2000;46:250-4.

37. Azuma T, Yoshikawa T, Araida T, Takasaki K. Differential diagnosis of polypoid lesion of the gallbladder by endoscopic ultrasonography. Am J Surg 2001;181:65-70.

38. Hirooka Y, Naitoh Y, Goto H, Ito A, Hayakawa S, Watanabe Y, et al. Contrast-enhanced endoscopic ultrasonography in gallbladder diseases. Gastrointest Endosc 1998;48:406-10.

39. Furukawa H, Kosuge T, Shimada K, Yamamoto J, Kanai Y, Mukai $\mathrm{K}$, et al. Small polypoid lesions of the gallbladder. Arch Surg 1998;133:735-9.

40. Kumaran V, Gulati S, Paul B, Pande K, Sahni P, Chattopadhyay $\mathrm{K}$. The role of dual-phase helical CT in assessing resectability of carcinoma of the gallbladder. Eur Radiol 2002;12:1993-9.

41. Kim JH, Kim TK, Eun HW. Preoperative evaluation of gallbladder carcinoma: efficacy of combined use of MR imaging, MR cholangigraphy, and contrast-enhanced dual phase three dimensional MR angiography. J Magn Reson Imaging 2002;16: 676-84.

42. Schwartz LH, Black J, Fong Y, Jarnagin W, Blumgart L, Gruen D, et al. Gallbladder carcinoma: findings at MR imaging with MR cholangiopancreatography. J Comput Assist Tomogr 2002;26: 405-10.

43. Menzel J, Hoepffner N, Sulkowski U, Reimer P, Heinecke A, Poremba C, et al. Polypoid tumors of the major duodenal papilla: preoperative staging with intraductal US, EUS, and CT-a prospective, histopathologically controlled study. Gastrointest Endosc 1999;49:349-57.

44. Itoh A, Goto H, Naitoh Y, Hirooka Y, Furukawa T, Hayakawa Tl. Intraductal ultrasonography in diagnosing tumor extension of cancer of the papilla of Vater. Gastrointest Endosc 1997;45: 251-60.

45. Weber SM, DeMatteo RP, Fong Y, Blumgart LH, Jarnagin WR. Staging laparoscopy in patients with extrahepatic biliary carcinoma. Analysis of 100 patients. Ann Surg 2002;235:3929. 
46. Kondo S, Nimura Y, Hayakawa N, Kamiya J, Nagino M, Uesaka $\mathrm{K}$. Regional and para-aortic lymphadenectomy in radical surgery for advanced gallbladder carcinoma. Br J Surg 2000;87:418-22.

47. Shimada H, Endo I, Togo S, Nakano A, Izumi T, Nakagawara G. The role of lymph node dissection in the treatment of gallbladder carcinoma. Cancer 1997;79:892-9.

48. Nishio H, Nagino M, Ebata T, Yokoyama Y, Igami T, Nimura Y. Aggressive surgery for stage IV gallbladder carcinoma; what are the contraindications? J Hepatobiliary Pancreat Surg 2007;14: $351-7$.

49. Kitagawa Y, Nagino M, Kamiya J, Uesaka K, Sano T, Yamamoto $\mathrm{H}$, et al. Lymph node metastasis from hilar cholangiocarcinoma: audit of 110 patients who underwent regional and paraaortic node dissection. Ann Surg 2001;233:385-92.

50. Poveski SP, Karpeh MS Jr, Conlon KC, Blumgart LH, Brennan MF. Association of preoperative biliary drainage with postoperative outcome following pancreatoduodenestomy. Ann Surg 1999;230:131-42.

51. Sewnath ME, Birjmohum RS, Rauws EA, Heiberegtes K, Obertop H, Gouma DJ. The effect of preoperative biliary drainage on postoperative complications after pancreatoduodenectomy. J Am Coll Surg 2001;192:726-34.

52. Martignoni ME, Wabner M, Krähhenbühl L, Redaelli CA, Friess $\mathrm{H}$, Bücher MW. Effect of preoperative biliary drainage on surgical outcome after pancreatoduodenectomy. Am J Surg 2001; 181:52-9.

53. Pisters PW, Hudec WA, Hess KR, Lee JE, Vauthey JN, Lahoti S, et al. Effect of preoperative biliary decompression on pancreatoduodenectomy. Associated morbidity in 300 consecutive patients. Ann Surg 2001;234:47-55.

54. Takada T. Is preoperative biliary drainage necessary according to evidence-based medicine? J Hepatobiliary Pancreat Surg 2001;8:58-64.

55. Nagino M, Kamiya J, Uesaka K, Sano T, Yamamoto H, Hayakawa $\mathrm{K}$, et al. Complications of hilar cholangiocarcinoma. World J Surg 2001;25:1277-83.

56. Farges O, Belghiti J, Kianmanesh R, Regimbeau JM, Santoro R, Vilgrain V, et al. Portal vein embolization before right hepatectomy: prospective clinical trial. Ann Surg 2003;237:208-17.

57. Hemming AW, Reed AI, Fujita S, Foley DP, Howard RJ. Surgical management of hilar cholangiocarcinoma. Ann Surg 2005; 241:693-9.

58. Seyama Y, Kubota K, Sano K, Noie T, Takayama T, Kosuge T, et al. Long-term outcome of extended hemihepatectomy for hilar bile duct cancer with no mortality and high survival rate. Ann Surg 2003;238:73-83.

59. Kawasaki S, Imamura H, Kobayashi A, Noike T, Miwa S, Miyagawa S. Results of surgical resection for patients with hilar bile duct cancer: application of extended hepatectomy after biliary drainage and hemihepatic portal vein embolization. Ann Surg 2003;238:84-92.

60. Kondo S, Hirano S, Ambo Y, Tanaka E, Okushiba S, Morikawa $\mathrm{T}$, et al. Forty consecutive resections of hilar cholangiocarcinoma with no postoperative mortality and no positive ductal margins: results of a prospective study. Ann Surg 2004;240:95-101.

61. Sano T, Shimada K, Sakamoto Y, Yamamoto J, Yamasaki S, Kosuge T. One hundred two consecutive hepatobiliary resections for perihilar cholangiocarcinoma with zero mortality. Ann Surg 2006;244:240-7.

62. Nagino M, Kamiya J, Nishio H, Ebata T, Arai T, Nimura Y. Two hundred forty consecutive portal vein embolizations before extended hepatectomy for biliary cancer: surgical outcome and long-term follow-up. Ann Surg 2006;243:364-72.

63. Nimura Y, Hayakawa N, Kamiya J, Kondo S, Shionoya S. Hepatic segmentectomy with caudate lobe resection for bile duct carcinoma of the hepatic hilus. World J Surg 1990;14:535-43.

64. Gazzaniga GM, Filauro M, Bagarolo C, Mori L. Surgery for hilar cholangiocarcinoma: Italian experience, J Hepatobiliary Pancreat Surg 2000;7:122-7.
65. Lee SG, Lee YJ, P ark KM, Hwang S, Min PC. One hundred and eleven liver resections for hilar bile duct cancer. J Hepatobiliary Pancreat Surg 2000;7:135-41.

66. Su CH, Tsay SH, Wu CC, Shyr YM, King KL, Lee CH, et al. Factors influencing postoperative morbidity, mortality, and survival after resection for hilar cholangiocarcinoma. Ann Surg 1996;223:384-94.

67. Kayahara M, Nagakawa T, Ohta T, Kitagawa H, Tajima H, Miwa $\mathrm{K}$. Role of nodal involvement and the periductal soft-tissue margin in middle and distal bile duct cancer. Ann Surg 1999; 229:76-83.

68. Jang JY, Kim SW, Park DJ, Ahn YJ, Yoon YS, Choi MG, et al. Actual long-term outcome of extrahepatic bile duct cancer after surgical resection. Ann Surg 2005;241:77-84.

69. Ebata T, Watanabe H, Ajioka Y, Oda K, Nimura Y. Pathological appraisal of lines of resection for bile duct carcinoma. Br J Surg 2002;89:1260-7.

70. Ebata T, Nagino M, Kamiya J, Uesaka K, Nagasaka T, Nimura Y. Hepatectomy with portal vein resection for hilar cholangiocarcinoma: audit of 52 consecutive cases. Ann Surg 2003;238: $720-7$.

71. Miyazaki M, Kato A, Ito H, Kimura F, Shimizu H, Ohtsuka M, et al. Combined vascular resection in operative resection for hilar cholangiocarcinoma: does it work or not? Surgery 2007;141: $581-8$.

72. Suzuki T, Yoshidome H, Kimura F, Shimizu H, Ohtsuka M, Kato A, et al. Renal function is well maintained after use of left renal vein graft for vascular reconstruction in hepatobiliary-pancreatic surgery. J Am Coll Surg 2006;202:87-92.

73. Hemming AW, Kim RD, Mekeel KL, Fujita S, Reed AI, Foley DP, et al. Portal vein resection for hilar cholangiocarcinoma. Am Surg 2006;72:599-604; discussion 604-5.

74. Nimura Y, Hayakawa N, Kamiya J, Maeda S, Kondo S, Yasui A, et al. Combined portal vein and liver resection for carcinoma of the biliary tract. Br J Surg 1991;78:727-31.

75. Miyazaki M, Itoh H, Ambiru S, Shimizu H, Togawa A, Gohchi E, et al. Radical surgery for advanced gallbladder carcinoma. Br J Surg 1996;83:478-81.

76. Kondo S, Nimura Y, Hayakawa N, Kamiya J, Nagino M, Uesaka $\mathrm{K}$. Extensive surgery for carcinoma of the gallbladder. Br J Surg 2002;89:179-84.

77. Klein P, Reingruber B, Kastl S, Dworak O, Hohenberger W. Is local excision of pT1-ampullary carcinomas justified?. Eur J Surg Oncol 1996; 22:366-71.

78. Paramythiotis D, Kleeff J, Wirtz M, Friess H, Büchler MW. Still any transduodenal local excision in tumors of the papilla of Vater? J Hepatobiliary Pancreat Surg 2004;11:239-44.

79. Beger HG, Treitschke F, Gansauge F, Harada N, Hiki N, Mattfeldt T. Tumor of the ampulla of Vater. Arch Surg 1999;134: 526-32.

80. Todoroki T, Iwasaki Y, Orii K, Otsuka M, Ohara K, Kawamoto $\mathrm{T}$, et al. Resection combined with intraoperative radiation therapy (IORT) for stage IV (TNM) gallbladder carcinoma. World J Surg 1991;15:357-66.

81. Todoroki T, Kawamoto T, Otsuka M, Koike N, Yoshida S, Takada $\mathrm{Y}$, et al. Benefits of combining radiotherapy with aggressive resection for stage IV gallbladder cancer. Hepatogastroenterology 1999;46:1585-91.

82. González González D, Gerard JP, Maners AW, De la LandeGuyaux B, Van Dijk-Milatz A, et al. Results of radiation therapy in carcinoma of the proximal bile duct (Klatskin tumor). Semin Liver Dis 1990;10:131-41.

83. Langer JC, Langer B, Taylor BR, Zeldin R, Cummings B. Carcinoma of the extrahepatic bile ducts: results of an aggressive surgical approach. Surgery 1985;98:752-9.

84. Stein DE, Heron DE, Rosato EL, Anne PR, Topham AK. Positive microscopic margins alter outcome in lymph node-negative cholangiocarcinoma when resection is combined with adjuvant radiotherapy. Am J Clin Oncol 2005;28:21-3. 
85. Speer AG, Cotton PB, Russell RC, Mason RR, Hatfield AR, Leung JW, et al. Randomised trial of endoscopic versus percutaneous stent insertion in malignant obstructive jaundice. Lancet 1987;2:57-62.

86. Smith AC, Dowsett JF, Russell RC, Hatfield AR, Cotton PB. Randomised trial of endoscopic stenting versus surgical bypass in malignant low bile duct obstruction. Lancet 1994;344:165560.

87. Davids PH, Groen AK, Rauws EA, Tytgat GN, Huibregtse K. Randomised trial of self-expanding metal stents versus polyethylene stents for distal malignant biliary obstruction. Lancet 1992:340:1488-92.

88. Kaassis M, Boyer J, Dumas R, Ponchon T, Coumaros D, Delcenserie R, et al. Plastic or metal stents for malignant stricture of the common bile duct? Results of a randomized prospective study. Gastrointest Endosc 2003;57:178-82.

89. Levy MJ, Baron TH, Gostout CJ, Petersen BT, Farnell MB. Palliation of malignant extrahepatic biliary obstruction with plastic versus expandable metal stents: an evidence-based approach. Clin Gastroenterol Hepatol 2004;2:273-85.

90. Hausegger KA, Thurnher S, Bodendörfer G, Zollikofer CL, Uggowitzer M, Kugler C, et al. Treatment of malignant biliary obstruction with polyurethane-covered Wallstents. AJR Am J Roentgenol 1998;170:403-8.

91. Isayama H, Komatsu Y, Tsujino T, Sasahira N, Hirano K, Toda N, et al. A prospective randomised study of "covered" versus "uncovered" diamond stents for the management of distal malignant biliary obstruction. Gut 2004;53:729-34.

92. Wagner HJ, Knyrim K, Vakil N, Klose KJ. Plastic endoprostheses versus metal stents in the palliative treatment of malignant hilar biliary obstruction. A prospective and randomized trial. Endoscopy 1993;25:213-6.
93. Glimelius B, Hoffman K, Sjödén PO, Jacobsson G, Sellström H, Enander LK, et al. Chemotherapy improves survival and quality of life in advanced pancreatic and biliary cancer. Ann Oncol 1996;7:593-600.

94. Takada T, Nimura Y, Katoh H, Nagakawa T, Nakayama T, Matsushiro T, et al. Prospective randomized trial of 5-fluorouracil, doxorubicin, and mitomycin $\mathrm{C}$ for nonresectable pancreatic and biliary carcinoma: multicenter randomized trial. Hepatogastroenterology 1998;45:2020-6.

95. Ishii H, Furuse J, Yonemoto N, Nagase M, Yoshino M, Sato T. Chemotherapy in the treatment of advanced gallbladder cancer. Oncology 2004;66:138-42.

96. Okusaka T, Ishii H, Funakoshi A, Yamao K, Ohkawa S, Saito S, et al. Phase II study of single-agent gemcitabine in patients with advanced biliary tract cancer. Cancer Chemother Pharmacol 2006;57:647-53.

97. Grove MK, Hermann RE, Vogt DP, Broughan TA. Role of radiation after operative palliation in cancer of the proximal bile ducts. Am J Surg 1991;161:454-8.

98. Tollenaar RA, van de Velde CJ, Taat CW, Gonzalez Gonzalez D, Leer JW, Hermans J. External radiotherapy and extrahepatic bile duct cancer. Eur J Surg 1991;157:587-9.

99. Ortner ME, Caca K, Berr F, Liebetruth J, Mansmann U, Huster $\mathrm{D}$, Voderholzer W, et al. Successful photodynamic therapy for nonresectable cholangiocarcinoma: a randomized prospective study. Gastroenterology 2003;125:1355-63.

100. Zoepf T, Jakobs R, Arnold JC, Apel D, Riemann JF. Palliation of nonresectable bile duct cancer: Improved survival after photodynamic therapy. Am J Gastroenterol 2005;100:2426-30. 